\title{
PIRMINĖS ASMENS SVEIKATOS PRIEŽIŪROS İTAIGŲ PASIRINKIMO MOTYVAI KAUNO MIESTE
}

\author{
Inga Krajauskaitė ${ }^{1}$, Daina Krančiukaitė-Butylkinienè $\dot{2}^{2,3}$ \\ ${ }^{1}$ Lietuvos sveikatos moksly universiteto Medicinos akademijos Medicinos fakultetas, \\ ${ }^{2}$ Lietuvos sveikatos mokslu universiteto Medicinos akademijos Šeimos medicinos klinika, \\ ${ }^{3}$ Lietuvos sveikatos moksly universiteto Medicinos akademijos Kardiologijos institutas
}

Raktažodžiai: ịstaigų pasirinkimo motyvai, viešosios gydymo įstaigos, privačios gydymo įstaigos.

\section{Santrauka}

Tyrimas atliktas $2017 \mathrm{~m}$. Tyrime dalyvavo 9 Kauno miesto pirminès asmens sveikatos priežiūros centrai. Anoniminès anketos apklausos būdu atsitiktinai apklausti 18 metų ir vyresni 374 pacientai (265 moterys ir 109 vyrai), besikreipiantys ị šeimos gydytoją. Tyrimui atrinkti asmenys suskirstyti į 2 grupes pagal gydymo įstaigą: besigydantys viešosiose (194 asmenys) ir privačiose (182 asmenys) pirminès sveikatos priežiūros ịstaigose. Nustatyti ir palyginti duomenys apie dabartinę gydymo įstaigą, jos pasirinkimo, keitimo motyvai. Duomenų statistinè analizė atlikta naudojant statistinių programų paketą (SPSS Version 24.0 for Windows) ir MS Excel. Skirtumas tarp grupių vertintas taikant $\chi^{2}$ testą. Skirtumas laikytas statistiškai reikšmingu, kai $\mathrm{p}<0,05$.

Dažniausi pirminès asmens sveikatos priežiūros ịstaigos pasirinkimo motyvai privačiose ir viešose gydymo įstaigose - patogumas atvykti (65,2 proc.), kokybiškos paslaugos $(39,8$ proc.) ir malonus personalas ( 21,7 proc.). Didžioji dauguma (77,3 proc.) rekomenduotų jų lankomą gydymo įstaigą savo artimiesiems, draugams.

Dažniausi pirminès asmens sveikatos priežiūros istaigos pasirinkimo motyvai buvo patogumas atvykti, kokybiškos paslaugos ir malonus personalas. Dauguma rekomenduotų savo gydymo ịstaigą artimiesiems, draugams.

\section{Ivadas}

Teisę ị sveikatą ir jos priežiūrą turi kiekvienas žmogus [1]. Svarbiausia sąlyga igyvendinti šią teisę: sveikatos prie- žiūros (SP) prieinamumas kiekvienam piliečiui, nepriklausomai nuo amžiaus, tautybès, gyvenamosios vietos, statuso bei kitų veiksnių [2]. Vienas pagrindinių sveikatos priežiūros sistemos tikslų - tai optimalus pacientų poreikių tenkinimas. Pacientų poreikiais turi rūpintis visi SP įstaigų darbuotojai bei siekti pritraukti kuo daugiau paslaugų vartotojų [3]. Visuotinai pripažinta, kad būtent pacientas turi vertinti, ar SP sistema orientuota ị jo poreikius, o paciento lūkesčių igyvendinimas Pasaulio sveikatos organizacijos (PSO) pripažintas vienu svarbiausių SP sistemos funkcionavimo rodiklių [4].

Per pastaraji dešimtmetį Lietuvoje reguliariai atliekami tyrimai siekiant nustatyti veiksnius, lemiančius SP gydymo ìstaigos pasirinkimą lemiančius veiksnius ir motyvaciją renkantis pirminę asmens SP įstaigą [5, 6]. Reguliuojant SP rinką, labai svarbu įvertinti kintančius veiksnius, lemiančius vartotojų pasirinkimą naudotis tiek privačiomis SP ịstaigų paslaugomis, tiek viešosiomis. Šie tyrimai yra reikalingi, norint objektyviau ịvertinti vykstančius pasikeitimus pirminèse asmens SP įstaigose, atskleisti silpnesnes veiklos sritis, sudaryti sąlygas konkuruoti tarpusavyje bei pagerinti teikiamų paslaugų kokybę.

Šio tyrimo tikslas - nustatyti gydymo ịstaigos pasirinkimo ir keitimo motyvus Kauno miesto pirminès asmens sveikatos priežiūros įstaigose.

\section{Tiriamųjų kontingentas ir tyrimo metodai}

Tyrime dalyvavo 9 Kauno miesto pirminès asmens SP centrai: 4 viešosios (Všț Kauno Dainavos poliklinika, VšI Kauno Kalniečių poliklinika, Všt Kauno Centro poliklinika, VšĮ Kauno Šilainių poliklinika) ir 5 privačios (,Vita Longa“ šeimos klinika, „Saulès“ šeimos medicinos centras, Šeimos ir odontologijos klinika „Signata“, „Ave Vita“ šeimos klinika, Šiaurès šeimos medicinos centras „Medgintras“) gydymo ịstaigos. Pirminès asmens SP centrai pasirinkti pagal prisirašiusių pacientų skaičių. Anoniminė anketinè pacientų apklausa 
buvo atliekama $2017 \mathrm{~m}$. Apklausti ị šeimos gydytojus šiuo laikotarpiu besikreipiantys atsitiktinai parinkti 18 metu ir vyresni 374 pacientai. Atlikti tyrimą gautas LSMU Bioetikos leidimas (2017-06-21, nr. BEC-MF-471). Tyrimui atsitiktinai atrinkti asmenys suskirstyti i 2 grupes pagal gydymo įstaigą: besigydantys viešosiose (194 asmenys) ir privačiose (182 asmenys) pirminès sveikatos priežiūros įstaigose. Klausimyną sudrè socialiniai ir demografiniai duomenys (lytis, amžius, išsilavinimas, socialine padètis), klausimai apie pirminę SP įstaigą, jos pasirinkimo, keitimo motyvai. Duomenų statistinè analizè atlikta naudojant statistinių programų paketą (SPSS Version 24.0 for Windows) ir MS Excel. Skirtumas tarp grupių vertintas taikant $\chi^{2}$ testą. Skirtumas laikytas statistiškai reikšmingu, kai $\mathrm{p}<0,05$.

\section{Rezultatai}

Iš visų tyrime dalyvavusių asmenų $(n=374)$ daugiau nei pusę sudarè moterys ( 70,9 proc., $n=265$ ). Pagal amžiaus grupes respondentai pasiskirste gana tolygiai, daugiausia atsakiusiujjų buvo $18-30$ metu ( 21,9 proc., $n=82)$ ir $31-40$ metų (17,9 proc., $\mathrm{n}=67)$ asmenys. Apie trečdali tyrimo dalyvių buvo igiję aukštaji universitetinị išsilavinimą (35,3 proc., $\mathrm{n}=132)$, mažesnis skaičius - vidurinị išsilavinimą ( 27,8 proc., $\mathrm{n}=104)$. Didžioji dalis respondentų buvo darbininkai (40,6 proc., $\mathrm{n}=152)$, o tarnautojų - dvigubai mažiau (20,6 proc., $\mathrm{n}=77)$. Iš visų tyrimo dalyvių ( $\mathrm{n}=374) 51,9$ proc. (194) sudare besigydantys viešosiose pirminès asmens SP ịstaigose, o 48,1 proc. $(\mathrm{n}=180)$ - privačiose pirminès asmens SP įstaigose.

Tiriamujuc teirautasi apie lankymosi laikotarpi dabartinëje gydymo ịstaigoje. Apie pusę atsakiusiųjų teigè, kad jau ilgą laiką (daugiau nei 10 metų) lankosi dabartinèje gydymo istaigoje ( 47,1 proc., $n=176)$, trečdalis - mažiau nei 5 metus (31,0 proc., $\mathrm{n}=118$ ) lankosi dabartinèje gydymo įstaigoje. Tyrimo dalyvių klausta, kodèl pasirinko būtent šią, dabartinę pirminès asmens SP ịstaigą. Respondentai galèjo atsakydami pasirinkti daugiau nei vieną atsakymo variantą. Dažniausias

1 lentelè. Gydymo įstaigos pasirinkimo motyvai $(n=374)$

\begin{tabular}{|l|l|}
\hline Motyvai & \multicolumn{1}{|c|}{ Respondentai n (proc.) } \\
\hline Yra arti gyvenamosios vietos & $244(65,2)$ \\
\hline Čia gaunu kokybiškas paslaugas & $149(39,8)$ \\
\hline Man patinka šios ǐstaigos aplinka & $58(15,5)$ \\
\hline $\begin{array}{l}\text { Greičiau aptarnauja, mažesnės ser- } \\
\text { gančiųų eilès }\end{array}$ & $45(12,0)$ \\
\hline Malonus personalas & $81(21,7)$ \\
\hline $\begin{array}{l}\text { Rekomendavo kiti (̌̌eimos nariai } \\
\text { ar pažĭstami) }\end{array}$ & $53(14,2)$ \\
\hline Kita & $3(0,8)$ \\
\hline
\end{tabular}

motyvas buvo mažas atstumas iki namų $-65,2$ proc. $(n=244)$ atsakiusiujų pasirinko gydymo ịstaigą dèl patogumo atvykti. Kitos priežastys - pasitenkinimas paslaugu kokybe $(39,8$ proc. $n=149)$ ir malonus personalo elgesys $(21,7$ proc. $n=81)$ (1 lentelè).

110 (29,4 proc.) respondentų nurodè, kad yra keitę gydymo îstaigą 5 metų laikotarpiu (1 pav.). Dažniausia keitimo priežastis - gyvenamosios vietos pakeitimas - taip teigè 50,9 proc. $(n=56)$ atsakiusiujų, antra pagal dažnị priežastis - nepasitenkinimas paslaugų kokybe (42,7 proc.; $n=47)$, trečioji- nemalonus personalas $(14,5$ proc.; $n=16)$ ir ketvirta - didelès sergančiujų eilès (13,6 proc.; $n=15)$ (2 lentelè).

Prieš pasirinkdami dabartinę pirminę asmens SP ịstaigą 260 (69,5 proc.) tyrimo dalyvių lankèsi viešosiose gydymo istaigose, 41 (11,0 proc.) - privačiose, ir 73 (19,5 proc.) respondentai teige, kad tai yra pirmoji įstaiga, kurioje lankosi, kitur anksčiau nesigydè (2 pav.).

Tyrime dalyvavusiujų teirautasi, ar dabartinę pirminę asmens SP įstaigą rekomenduotų pažistamiems/artimiesiems. Apklausos duomenys rodo, kad didžioji dalis $-77,3$ proc. $(n=289)$ rekomenduotų jų lankomą pirminę asmens SP ịstaigą savo artimiesiems, draugams, 17,4 proc. $(n=65)$ nežino/ abejoja, o 20 atsakiusiujų (5,3 proc.) - nerekomenduotų. Privačias gydymo įstaigas savo pažįstamiems/artimiesiems rekomenduotų didesnè dalis atsakiusiujų ( 83,3 proc., $\mathrm{n}=150)$, lyginant su viešujų pirminès asmens SP įstaigų pacientais (71,6 proc., $\mathrm{n}=139, \mathrm{p}=0,015$ ). Mažesnè dalis privačių gydymo ịstaigų respondentų nežino/abejoja (13,9 proc., $n=25)$, ar rekomenduotų savo dabartinę gydymosi įstaigą pažįstamiems/artimiesiems arba išvis - nerekomenduotų ( 2,8 proc., $\mathrm{n}=5)$, lyginant su viešujų ịstaigų tyrimo dalyviais atitinkamai (20,6 proc., $\mathrm{n}=40$ ir 7,7 proc.; $\mathrm{n}=15)$ ( 3 pav.).

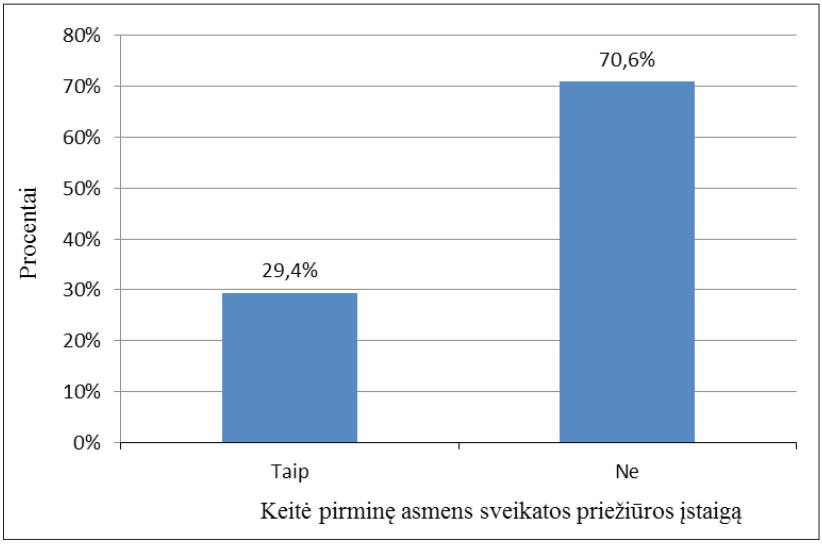

1 pav. Pirminès asmens sveikatos priežiūros įstaigos keitimas 5 metų laikotarpiu ( $\mathrm{n}=374)$. 


\section{Rezultatų aptarimas}

Pagal LR galiojančius įstatymus kiekvienas žmogus turi teisę $\mathfrak{i}$ artimiausios jo gyvenamai vietai ar lengvai pasiekiamos pirminès asmens SP įstaigos pasirinkimą. Norint sužinoti, ar aktyviai Kauno gyventojai naudojasi šia teise, tyrimo dalyvių buvo klausiama, kiek laiko gydosi dabartineje gydymo įstaigoje. Apie pusę atsakiusiujų nurodè, kad ilgą laiką - daugiau nei 10 metų lankosi dabartinèje gydymo įstaigoje (47,1 proc.). Apie trečdalis nurodè, kad dabartineje klinikoje lankosi mažiau nei 5 metus (31,0 proc.). Svarbus veiksnys, lemiantis gydymo ịstaigos pasirinkimą, yra jos prieinamumas. Tyrimo dalyvių klausiant, kodèl rinkosi būtent šią pirminès asmens

2 lentelè. Pirminès asmens sveikatos priežiūros įstaigos keitimo priežastys $(\mathrm{n}=110)$

\begin{tabular}{|l|c|}
\hline Priežastys & Tiriamieji n (proc.) \\
\hline Dėl gyvenamosios vietos pakeitimo & $56(15,0)$ \\
\hline Netenkino paslaugų kokybė & $47(12,6)$ \\
\hline Nepasitikejjau įstaigos personalo darbu & $10(2,7)$ \\
\hline Rekomendavo kiti & $9(2,4)$ \\
\hline Buvo didesnės sergančiujų eilès & $15(4,0)$ \\
\hline Nemalonus personalas & $16(4,3)$ \\
\hline Nepatiko ịstaigos aplinka & $9(2,4)$ \\
\hline Kita & $2(0,5)$ \\
\hline
\end{tabular}

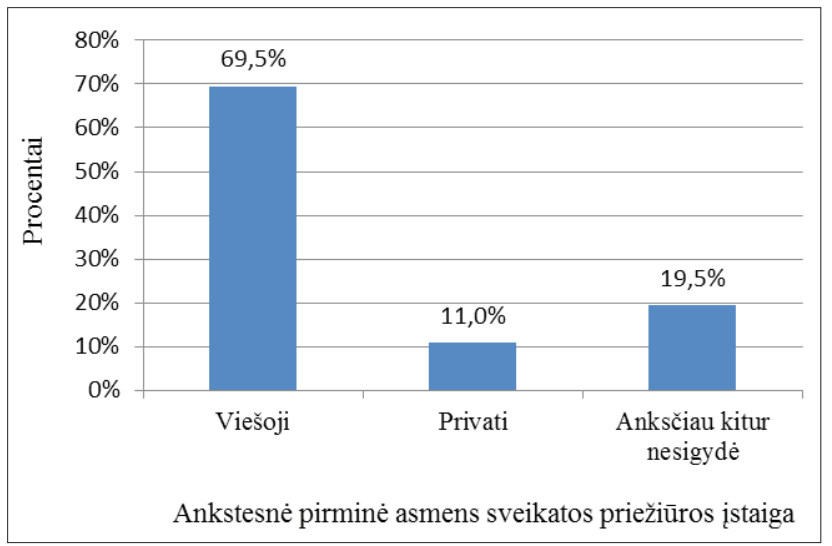

2 pav. Pacientų lankymasis pirminèje asmens sveikatos priežiūros įstaigoje prieš pasirenkant dabartinę gydymo ịstaigą $(n=374)$.
SP įstaigą, dažniausias motyvas buvo mažas atstumas iki namų - 65,2 proc. atsakiusiųų pasirinko gydymo ịstaigą dèl patogumo atvykti. 39,8 proc. ir 21,7 proc. respondentų atitinkamai pasirinko pirminę asmens SP ịstaigą dèl gaunamų kokybiškų paslaugų ir malonaus personalo elgesio. Šie gauti duomenys patvirtina B. Goštautaitès ir kt. tyrimo rezultatus, kad pacientas dažniausiai pasirenka arčiausiai namų esančią pirminès asmens SP ịstaigą, kuri teikia kokybiškas medicinines paslaugas [7]. Pacientu pasitenkinimas paslaugomis ir jų lūkesčių tenkinimas tampa pagrindine gydymo įstaigos sveikatos paslaugų kokybės gerinimo kryptimi [8]. Netenkinanti paslaugų kokybė lemia paciento sprendimą keisti pirminès asmens SP įstaigą, dèl ko didejja konkurencija tarp gydymo ịstaigų, privataus ir viešojo sektoriaus.

Tyrimo metu buvo klausiama, ar per 5 metus respondentai keite gydymo įstaigą. Tik trečdalis atsakiusiųjų (28,6 proc.) nurodè, kad keitè gydymo įstaigą per 5 metus, o didžioji dalis $(71,4$ proc.) neigè tą dariusi. Tai nurodo, kad dauguma pacientų yra patenkinti savo pasirinkta gydymosi ịstaiga. Pagrindiniai motyvai, kodèl respondentai keitè pirminę asmens SP ịstaigą 5 metų laikotarpiu, buvo gyvenamosios vietos pakeitimas - teritorinis prieinamumo pasikeitimas (50,9 proc.), nepasitenkinimas SP kokybe (42,7 proc.) ir nemalonus personalas (15,4 proc.). Gauti rezultatai pagrindžia ir kitų atliktų tyrimų rezultatus. J. Raibovskajos atliktoje apklausoje Vilniaus mieste nustatyta, kad 77,5 proc. respondentų nurodè keitę pirminę asmens SP ịstaigą 5 metų laikotarpiu daugiausia dèl gyvenamosios vietos (37,9 proc.), noro gauti geresnès kokybės paslaugas $(21,4$ proc.) bei nepasitenkinimo paslaugų kokybe (20,0 proc.) [9]. F. Mercado ir kt. atliktoje apklausoje nustatyta, kad pacientams svarbu kokybiška medicininè priežiūra, pakankamas personalo ben- 
dravimas ir malonus elgesys, nes priešingu atveju gali keisti dabartinę pirminès asmens SP ịstaigą [10].

Analizuojant mūsų tyrimo rezultatus buvo nustatyta, kad prieš pasirinkdami pirminę asmens SP įstaigą didžioji dalis atsakiusiujų (69,5 proc.) lankèsi viešojoje gydymo įstaigoje, 19,5 proc. - anksčiau kitur nesigydè, tai yra pirmoji jų pirminè asmens SP įstaiga, ir 11,0 proc. tyrimo dalyvių anksčiau gydèsi privačioje pirminès asmens SP įstaigoje. Galima daryti prielaidą, kad tyrimo dalyviai buvo nepatenkinti gaunamų medicininių paslaugų kokybe, dèl to keitė pirminę asmens SP įstaigą. Kalifornijoje atlikto tyrimo duomenimis nustatyta, kad beveik pusei (46 proc.) tyrimo dalyvių teko keisti pirminę asmens SP įstaigą dèl blogos patirties su medicinos personalu [11].

Mūsų atliktos apklausos duomenys rodo, kad didžioji dalis - 77,3 proc. tyrimo dalyvių rekomenduotų dabartinę pirminès asmens SP ịstaigą artimiesiems ir pažịstamiems. Privačias gydymo ịstaigas rekomenduotų didesnè atsakiusiujų dalis ( 83,3 proc.), lyginant su viešujų pirminès asmens SP ịstaigų pacientais (71,6 proc.). Tai ịrodo privataus sektoriaus SP paslaugas teikiančiu įstaigų didejjantị pranašumą prieš viešajį sektorių. Vienas pagrindinių sveikatos priežiūros paslaugas teikiančių ịstaigų tikslų - pacientų poreikių tenkinimas. Geresnis pacientų pasitenkinimas įstaigoje teikiamomis SP paslaugomis didina klinikos rekomendavimo tikimybę giminaičiams ir draugams [12].

\section{Išvados}

1. Dažniausias pirminès asmens sveikatos priežiūros ịstaigos pasirinkimo motyvas privačiose ir viešosiose gydymo ịstaigose - patogumas atvykti (65,2 proc.), kitos priežastys - pasitenkinimas paslaugų kokybe (39,8 proc.) bei malonus personalo elgesys (21,7 proc.).

2. Dažniausia pirminès asmens sveikatos priežiūros ịstaigos keitimo priežastis buvo gyvenamosios vietos pakeitimas - taip teigė 50,9 proc. atsakiusiujų, antra pagal dažni - nepasitenkinimas paslaugų kokybe (42,7 proc.), trečioji priežastis - nemalonus personalas (14,5 proc.) ir ketvirta didelès sergančiujų eilès (13,6 proc.).

3. Didžioji dalis $-77,3$ proc. rekomenduotų jų lankomą pirminę asmens SP ịstaigą savo artimiesiems, draugams. Privačias gydymo įstaigas savo pažịstamiems/artimiesiems rekomenduotų didesnè dalis atsakiusiųų ( 83,3 proc.), lyginant su viešujų pirminès asmens sveikatos priežiūros įstaigu pacientais ( 71,6 proc.).

\section{Literatūra}

1. Visuotinė žmogaus teisių deklaracija. Valstybės žinios, 2006;682497.

2. Maželis M. Pirminės sveikatos priežiūros paslaugų kokybės vertinimas pacientų ir gydytojų požiūriu Šiaulių centro poliklinikoje. Magistro darbas. Kaunas, 2013.

3. Dubakienè A. Pacientų požiūris apie pirminès sveikatos priežiūros centre teikiamas paslaugas ir jų prieinamumą. Magistro darbas. Kaunas, 2017.

4. Jaruševičienė L., Zaborskis A., Valius L. ,,Vartininko“ vaidmenị atliekančių šeimos gydytojų galimybẻs prižiūrèti paauglių lytinę ir reprodukcinę sveikatą. Lietuvos bendrosios praktikos gydytojas, 2010;14(3):160-8.

5. Kairys J. Opinion of patients and medical community on health care services in Lithuania: Review of research works submitted for habilitation procedure. Vilnius, 2009.

6. Jakubsevičienė R. Veiksnių, lemiančių šeimos gydytojo pasirinkimą, ịvertinimas. Magistro darbas. Kaunas, 2013.

7. Goštautaitė B., Jankauskienè D., Išganaitis V. Pacientų ir sveikatos priežiūros paslaugų teikèjų pasitenkinimo teikiamų paslaugų kokybe bei prieinamumu analizè. LR sveikatos apsaugos ministerija, 2011.

8. Frampton S, Guastello S, Brady C, Hale M, Horowitz S, Smith SB et al. Patient - centred care improvement guide 2008. Prieiga per internetą: http://www.hqontario.ca/Portals/0/modals/ qi/en/processmap_pdfs/tools/patient-centered $\% 20$ care $\% 20$ improvement $\% 20$ guide.pdf (paskutinioji prisijungimo data: 201710 17).

9. Rabkovskaja J. Slaugos paslaugų vertinimas privačiose ir viešose pirminès asmens sveikatos priežiūros ịstaigose: pacientų požiūris. Magistro darbas. Vilnius, 2016.

10. Mercado F, Mercado M, Myers N, Hewit M, Haller NA. Patient preferences in choosing a primary care physician. Journal of Primary Care And Community Health 2012;3(2):125-31. https://doi.org/10.1177/2150131911421802

11. Harris KM. How do patients choose physicians? Evidence from a national survey of enrollees in employment-related health plans. HSR: Health Services Research 2003; 38(2):711-32. https://doi.org/10.1111/1475-6773.00141

12. Stundžienė R., Kairys J., Čepanauskienė R. Pacientų nuomonė apie Šeškinès poliklinikoje teikiamas registravimo paslaugas. Sveikatos mokslai, 2011;21(6):115-20.

\section{ASSESMENT OF FACTORS DETERMINING THE CHOICE OF HEALTH CARE INSTITUTIONS IN KAUNAS}

I.Krajauskaitė, D.Krančiukaitė-Butylkinienė

Key words: motives of choosing health care institutions, private health care service, public health care service.

Summary

Objective. To evaluate factors that determine the choice of pirmary heatlh care institution in Kaunas.

Research method. The research was done during the year of 2017 by anonymous questionnaire 374 randomly selected patients over the age of 18 (265 women and 109 men) were questioned, who applied to family doctor. The selected patients for the research were divided into two groups based on a health care institu- 
tion: patients who attend public (194 individuals) and private (182 individuals) primary health care centres. Patients attitude to choice of certain primary health care institution, its determinational factors, replacement motives were analyzed and compared. The data analysis was performed using a statistical program package (SPSS Version 24.0 for Windows). The differences between the groups were evaluated using $\chi^{2}$ test. The disparity is considered statistically significant, when $\mathrm{p}<0.05$.

Results. The most common factors for choosing a certain primary health care institution were convenience - close to the residence $(65.2 \%)$, high quality of services $(39.8 \%)$ and friendly personnel $(21.7 \%)$. The majority $(77.3 \%)$ of respondents would recommend their primary health care institution to relatives and friends.

Conclucions. The most common criteria for selecting a certain primary health care institution were convenience (close to the residence), high quality of services and friendly personnel. The majority of respondents would recommend their primary health care institution to relatives and friends.

Correspondence to: krajauskaite.inga@gmail.com

Gauta 2018-04-10

\section{KVIEČIAME PRENUMERUOTI “SVEIKATOS MOKSLŲ” ŽURNALĄ 2018 METAIS!}

Žurnalas "Sveikatos mokslai" (Index Copernicus, EBSCO host (Academic Search Complete), Gale (Academic OneFile), ProQuest (Ulrich's, Summon), Australia (ERA) 2012 Journal List (ERA ID 34962) skirtas visų specialybių gydytojams, slaugytojams ir kitiems specialistams, spausdina mokslinius straipsnius lietuvių, anglų kalbomis. Reikalavimai straipsniams atitinka mokslo leidiniams keliamus reikalavimus. Žurnalas kioskuose neparduodamas. Žurnalą, kuris leidžiamas kartą per du mènesius, galima užsiprenumeruoti visuose Lietuvos pašto skyriuose, taip pat internetu: www.prenumeruok.It Prenumeratos kaina nesikeičia: visiems metams - 34,75 EUR, šešiems mėnesiams - 17,37 EUR, keturiems mėnesiams - 11,58 EUR, dviem mėnesiams - 5,79 EUR. Prenumeratos kodas: 5348. Žurnalo autoriams straipsnių spausdinimas mokamas.

Redakcija 